\title{
Some Properties of a Chitinase from a Marine Luminous Bacterium, Vibrio fischeri Strain COT-A136
}

\author{
Shigeki Fukasawa, ${ }^{*, a}$ Masaru AraI, ${ }^{a}$ Tadao WADA, ${ }^{a}$ Hidekuni Shima ${ }^{b}$ and Munetsugu Kurata ${ }^{c}$ \\ Department of Chemistry, Faculty of Science, ${ }^{a}$ and Department of Physiological Chemistry, Faculty of Pharmaceutical Sciences, ${ }^{c}$ Josai University, Sakado, \\ Saitama 350-02, Japan and Pharmacology Research, Fuji Chemical Institutes, Ltd., 530 Chohkeiji, Takaoka 933, Japan. Received October 23, 1991
}

\begin{abstract}
A chitinolytic, luminous bacterium was isolated from the intestine of a fish, Oplegnathus tunctatus, and identified as Vibrio fischeri. A chitinase from the culture supernatant of the intestinal luminous strain, $V$. fischeri COT-A136, was purified. The purified chitinase had a molecular weight of 63000 , comprising a dimer of 31500 molecular weight subunits. The enzyme was most active at $\mathrm{pH} 6.0$ and $45^{\circ} \mathrm{C}$, and stable below $40^{\circ} \mathrm{C}$. The chitinase had high activities at $2 \%$ through $5 \% \mathrm{NaCl}$ concentration, but the activity was suppressed at low and high $\mathrm{NaCl}$ concentrations.
\end{abstract}

Keywords chitinase; luminous bacterium; marine bacterium; Vibrio fischeri

\section{Introduction}

Chitinase (EC3.2.1.14) is widely distributed in animals, plants and microorganisms. Microbial chitinases have been purified from cultures of genera such as Streptomyces, ${ }^{1-4)}$ Serratia, ${ }^{5,6)}$ Vibrio $^{7)}$ and Aeromonas. ${ }^{8)}$

Recently, marine luminous bacteria were isolated from the gut of the fish, Oplegnathus tunctatus, in our laboratory, and high extracellular chitinase activity was found in the culture supernatants of most of these luminous strains.

In this paper we describe the purification and some properties of extracellular chitinase from one of these intestinal luminous strains.

\section{Experimental}

Materials and Isolation The fish, Oplegnathus tunctatus, which was collected in Amami (Okinawa, Japan), was kindly donated by Mr. R. Satoh of Taiyo Central R \& D Institutes, Taiyo Fishery Co., Ltd. The isolation of intestinal luminous bacteria was carried out by the method previously described.9)

Detection of Extracellular Chitinase Activity Extracellular chitinase activity was detected on chitin seawater agar plates that consisted of $10 \mathrm{~g}$ of chitin powder (Nacalai Tesque, Kyoto, Japan) per liter and NC agar medium. ${ }^{10)}$ The NC broth medium lacking agar is usually used as a basal medium. The inoculated chitin seawater agar medium was incubated at $25^{\circ} \mathrm{C}$ for $2-7 \mathrm{~d}$. Clear zones indicating chitinolytic activity could be seen around the colonies of extracellular chitinase producing bacteria.

Cultivation for Preparation of Chitinase The culture medium consisted of the basal medium described above and $10 \mathrm{~g}$ of chitin powder per liter. Cultivation was carried out at $23^{\circ} \mathrm{C}$ for $6 \mathrm{~d}$ by the method previously described.$^{9)}$ After cultivation, the cells were removed from the culture by centrifugation at $12000 \times \mathrm{g}$.

Assay of Chitinase Activity The chitinase activity was measured according to the methods of Jeuniaux ${ }^{11)}$ and Yabuki et al. ${ }^{8)}$ The assay mixture was composed of $1.4 \mathrm{ml}$ of colloidal chitin suspension, $1.4 \mathrm{ml}$ of $0.1 \mathrm{M}$ Tris- $\mathrm{HCl}$ buffer ( $\mathrm{pH} 7.8$ ) containing $6 \% \mathrm{NaCl}$ and $0.2 \mathrm{ml}$ of the enzyme solution. The initial absorbance at $610 \mathrm{~nm}$ of the assay mixture was adjusted from 0.5 to 0.8 . After incubation for $60 \mathrm{~min}$ at $30^{\circ} \mathrm{C}$, absorbance at $610 \mathrm{~nm}\left(A_{610}\right)$ of the assay mixture was determined with a Shimadzu UV-120-02 spectrophotometer. One unit of activity was defined as the amount of enzyme that caused a $1 \%$ decrease in $A_{610}$ per min per $\mathrm{ml}$. The enzyme solution was adjusted to a level such that the decrease in $A_{610}$ did not exceed $20 \%, \beta$ - $N$-Acetylglucosaminidase and $\beta-N$ acetylgalactosaminidase activities were measured according to the method of Ohtakara et al. ${ }^{12)}$ Lysozyme activity was measured by the method of Koga et al. ${ }^{13)}$

Identification Identification of the bacterial isolates was carried out according to the methods of Reichelt and Baumann, ${ }^{14)}$ Jensen et al.,${ }^{15)}$ Baumann and Baumann, ${ }^{16)}$ Yang et al. ${ }^{17)}$ and Baumann et al. ${ }^{18)}$ as previously described. ${ }^{19)}$

Determination of Protein Concentration Protein concentration was determined by the method of Lowry et al. ${ }^{20)}$ with bovine serum albumin as a standard.

Electrophoresis Polyacrylamide disc gel electrophoresis (PAGE) was performed by the method of Davis. ${ }^{21)}$ Sodium dodecyl sulfate-PAGE
(SDS-PAGE) was performed by the method of Weber and Osborn. ${ }^{22)}$

Measurement of Molecular Weight The molecular weight of the purified enzyme was estimated by SDS-PAGE and gel filtration on a column of Sephadex G-100 superfine $(1.5 \times 95 \mathrm{~cm})$ by the method of Determann and Michel. ${ }^{23)}$

Chemicals Chitin powder was purchased from Nacalai Tesque Inc., Kyoto, Japan. $p$-Nitrophenyl- $\beta$ - $N$-acetylglucosaminide and $p$-nitrophenyl $-\beta-N$-acetylgalactosaminide were obtained from Sigma Chemical Co., St. Louis, U.S.A. Other chemicals were obtained from Wako Pure Chemical Industries Ltd., Osaka, Japan.

\section{Results and Discussion}

Identification of the chitinolytic, luminous bacterium COT-A136 was carried out. The COT-A136 strain is a moderately luminous, motile gram-negative, rod. It was negative for the traits of accumulation of poly- $\beta$-hydroxybutyrate, production of gas on fermentation of D-glucose and activity of arginine dihydrolase. The COT-A136 strain grew at 20,30 and $35^{\circ} \mathrm{C}$, but not at 4 and $40^{\circ} \mathrm{C}$. As sole carbon and energy sources, it utilized maltose, cellobiose and L-proline, but was unable to grow on D-glucuronate, mannitol, D- $\alpha$-alanine, DL- $\beta$-hydroxybutyrate, acetate, propionate, L-tyrosine, pyruvate, $\alpha$-ketoglutarate, sucrose, salicin, caprylate and pelargonate. The COT-A136 strain did not produce amylase, gelatinase and lipase. These results indicate that the intestinal luminous strain, COT-A136, is a strain of Vibrio fischeri.

The purification of the chitinase from $V$. fischeri COTA136 is summarized in Table I. Ammonium sulfate was added to the culture supernatant $(2600 \mathrm{ml})$ to $100 \%$ saturation. The precipitate was dissolved in an aliquot of $10 \mathrm{~mm}$ Tris- $\mathrm{HCl}$ buffer ( $\mathrm{pH} 7.8$ ) and then dialyzed against $5 \mathrm{~mm}$ Tris- $\mathrm{HCl}$ buffer ( $\mathrm{pH} 7.8$ ) at $4{ }^{\circ} \mathrm{C}$ for $5 \mathrm{~d}$. The dialyzate $(1500 \mathrm{ml})$ was mixed with DEAE-Sephacel equilibrated with $10 \mathrm{~mm}$ Tris- $\mathrm{HCl}$ buffer $\left(\mathrm{pH} \mathrm{7.8)}\right.$ at $20^{\circ} \mathrm{C}$. The chitinase was eluted with the same buffer containing $0.8 \mathrm{M} \mathrm{NaCl}$ and

TABLE I. Summary of Purification of the Chitinase from $V$. fischeri COT-A136

\begin{tabular}{lcccc}
\hline \hline Procedure & $\begin{array}{c}\text { Total } \\
\text { activity } \\
\text { (units) }\end{array}$ & $\begin{array}{c}\text { Total } \\
\text { protein } \\
\text { (mg) }\end{array}$ & $\begin{array}{c}\text { Specific } \\
\text { activity } \\
\text { (units/mg) }\end{array}$ & $\begin{array}{c}\text { Recovery } \\
(\%)\end{array}$ \\
\hline Culture supernatant & 3600 & 1090 & 3.3 & 100 \\
Ammonium sulfate & 2500 & 310 & 8.1 & 69 \\
precipitation & 1400 & 120 & 11.7 & 39 \\
DEAE-Sephacel & 950 & 68 & 14.0 & 26 \\
Sephadex G-100 & & & & \\
\hline
\end{tabular}




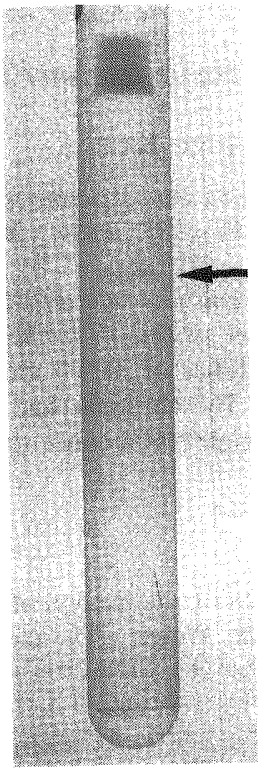

Fig. 1. PAGE of the Purified Chitinase

Electrophoresis was done using 10\% gel as described in Experimental. Protein was stained with Coomassie Brilliant Blue R-250.

$3 \mathrm{~m}$ urea, because little enzyme was eluted with the buffer containing $0.8 \mathrm{M} \mathrm{NaCl}$ or the buffer containing $0.8 \mathrm{M} \mathrm{NaCl}$ and $1 \mathrm{M}$ urea. On the other hand, $\beta-N$-acetylglucosaminidase and $\beta$ - $N$-acetylgalactosaminidae activities were detected in the fractions eluted with the buffer containing $0.2 \mathrm{M} \mathrm{NaCl}$.

The active fractions of chitinase were combined and then applied to a Sephadex G-100 column $(3.0 \times 45 \mathrm{~cm})$ equilibrated with the same buffer at $4^{\circ} \mathrm{C}$. The chitinase was eluted as a single peak and then collected. No lysozyme activity was detected in this fraction.

The purified chitinase had a specific activity of 14.0 units per mg of protein and showed 4.2-fold purification over the original culture supernatant, with $26 \%$ recovery. The purified enzyme showed a single protein band on PAGE (Fig. 1) and SDS-PAGE. After electrophoresis (PAGE), the gel was sliced in test tubes with the buffer. The chitinase activity was detected in the eluate from the gel corresponding to the stained band.

The subunit molecular weight of the chitinase from $V$. fischeri COT-A136 was estimated to be 31500 by SDSPAGE. On Sephadex G-100 superfine gel filtration, the molecular weight of the purified enzyme was estimated to be 63000 , suggesting that the enzyme is a dimer.

The molecular weights of some microbial chitinases have been reported, i.e., 33000 and 25000 for chitinases I and II of Streptomyces orientalis, ${ }^{31} 60000$ for Vibrio sp. ${ }^{7)}$ and 115000 for Aeromonas hydrophila subsp. anaerogenes A52. ${ }^{8)}$

The molecular weight of the chitinase from the COTA136 was similar to that of Vibrio sp. ${ }^{71}$

The chitinase activity of the marine, intestinal luminous bacterium, COT-A136, was affected by $\mathrm{NaCl}$ concentration, as shown in Fig. 2. This chitinase exhibited high activity at $\mathrm{NaCl}$ concentrations ranging from $3 \%$ to $5 \%$, but the activity was suppressed at both low and high $\mathrm{NaCl}$ concentrations. Whereas the proteinase from luminous bacteria, $V$. splendidus and $V$. logei, exhibited higher ac-

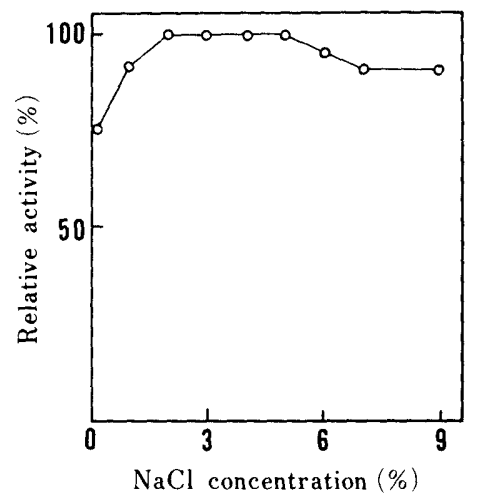

Fig. 2. Effect of $\mathrm{NaCl}$ Concentration on the Activity of the Purified Chitinase

tivities at low $\mathrm{NaCl}$ concentration ${ }^{9,19)}$ and the activity of agarase from a luminous strain, $V$. harveyi FLB-17, was suppressed at low $\mathrm{NaCl}$ concentration, but not affected from $3 \%$ to $8 \% \mathrm{NaCl}^{24)}$ Regarding the effect of $\mathrm{NaCl}$ concentration on the enzyme activity, the property of this chitinase was different from that of the proteinases and the agarase.

The optimum $\mathrm{pH}$ of the purified chitinase was $\mathrm{pH} 5.0$ 6.0. The chitinases from bacteria, Vibrio sp. ${ }^{7)}$ and $A$. hydrophila subsp. anaerogenes A $52^{8)}$ were most active at $\mathrm{pH} 6-8$ and $\mathrm{pH}$ 7. The optimum $\mathrm{pH}$ of this chitinase was lower than that of previously reported chitinases.

The purified chitinase was stable below $40^{\circ} \mathrm{C}$ and most active at $45^{\circ} \mathrm{C}$, which was similar to that of $A$. hydrophila subsp. anaerogenes A52. ${ }^{8)}$

The distribution of luminous bacteria in the intestine of the fish, Oplegnathus tunctatus, examined in this study was diverse corresponding to intestinal microflora. The ratio of the numbers of luminuos bacteria, which ranged in density from $10^{3}$ to $10^{4}$ cells per centimeter of the intestine, against total intestinal bacteria, that could grow on $\mathrm{MN}$ agar (nutritionally complete medium ${ }^{25}$ ) at $20^{\circ} \mathrm{C}$ for $48 \mathrm{~h}$, was observed more than $10 \%$ on average.

It may be considered that these enzymes contribute to making up a major population with luminous bacteria in the intestinal microflora.

Acknowledgments The authors are grateful to Dr. Y. Haneda for his helpful advice. The authors also wish to thank Mr. R. Satoh and Taiyo Fishery Co., Ltd., for giving us the fish.

\section{References}

1) C. Jeuniaux, Arch. Int. Physiol. Biochem., 67, 597 (1959)

2) J. Skujins, A. Pukite and A. D. McLaren, Enzymologia, 39, 353 (1970).

3) Y. Tominaga and Y. Tsujisaka, Agric. Biol. Chem., 40, 2325 (1976).

4) S. Hara, Y. Yamamura, Y. Fujii and T. Ikenaka, "Proceedings of the Second International Conference on Chitin and Chitonsan," ed. by S. Hirano and S. Tokura, the Japanese Society of Chitin and Chitosan, 1982, p. 125.

5) J. Monreal and E. T. Reese, Can. J. Microbiol., 15, 689 (1969).

6) R. L. Roberts and E. Cabib, Anal. Biochem., 127, 402 (1982).

7) A. Ohtakara, M. Mitsutomi and Y. Uchida, J. Ferment. Technol., 57, 169 (1979).

8) M. Yabuki, K. Mizushima, T. Amatatsu, A. Ando, T. Fujii, M. Shinada and M. Yamashita, J. Gen. Appl. Microbiol., 32, 25 (1986).

9) S. Fukasawa, S. Takei, R. Satou, H. Shima and M. Kurata, Chem. Pharm. Bull., 38, 1644 (1990).

10) S. Fukasawa, P. V. Dunlap, M. Baba and M. Osumi, Agric. Biol. 
Chem., 51, 265 (1987).

11) C. Jeuniaux, "Methods in Enzymology," Vol. 8, ed. by E. F. Neufeld and V. Ginsburg, Academic Press, New York, 1966, p. 644.

12) A. Ohtakara and K. N. T. Thi, Nippon Nogeikagaku Kaishi, 52, 589 (1978).

13) D. Koga, T. Imoto, S. Tanaka, A. Ida and K. Yagishita, Agric. Biol. Chem., 47, 1941 (1983).

14) J. L. Reichelt and P. Baumann, Arch. Mikrobiol., 94, 283 (1973).

15) M. J. Jensen, B. M. Tobo, P. Baumann, M. Mandel and K. H. Nealson, Cur. Microbiol., 3, 311 (1980).

16) P. Baumann and L. Baumann, "The Prokaryotes,". ed. by M. P. Starr, H. Stolp, H. G. Trupper, A. Balows and H. G. Schlegel, Springer-Verlag, Berlin, Heidelberg and New York, 1981, p. 1301, Chapter 104.

17) Y. Yang, L. Yeh, Y. Cao, L. Baumann, P. Baumann, J. S. Tang and B. Beaman, Cur. Microbiol., 8, 95 (1983).

18) P. Baumann, R. H. W. Schubert, A. L. Furniss, J. V. Lee and L. Baumann, "Bergey's Manual of Systematic Bacteriology," Vol. 1, ed. by N. R. Kreig and J. G. Holt, Williams and Wilkins, Baltimore and London, 1984, p. 516.

19) S. Fukasawa, S. Aoki, N. Gawazawa and M. Osumi, Agric. Biol. Chem., 52, 427 (1988).

20) O. H. Lowry, N. J. Rosebrough, A. L. Farr and R. J. Randall, J. Biol. Chem., 193, 265 (1951).

21) B. J. Davis, Ann. N. Y. Acad. Sci., 121, 404 (1964)

22) K. Weber and M. Osborn, J. Biol. Chem., 244, 4406 (1969).

23) H. Determann and W. Michel, J. Chromatogr., 25, 303 (1966).

24) S. Fukasawa and H. Kobayashi, Agric. Biol. Chem., 51, 269 (1987)

25) S. Fukasawa and P. V. Dunlap, Agric. Biol. Chem., 50, 1645 (1986). 